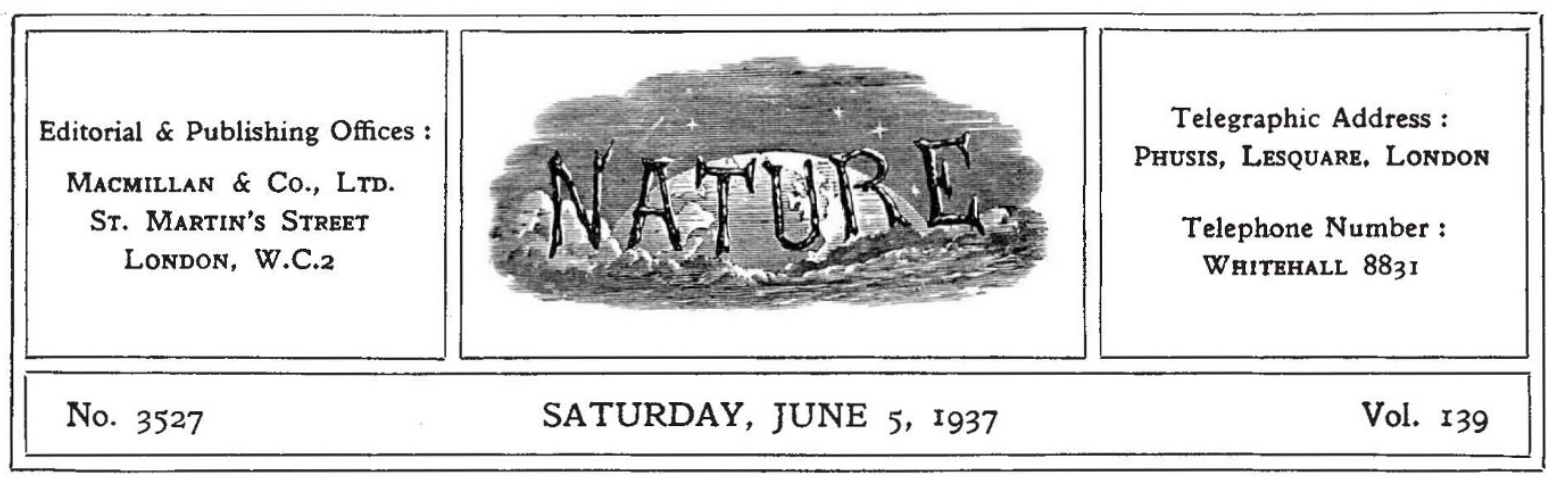

\title{
Freedom of the Mind
}

$\mathrm{O}^{\mathrm{u}}$ UR civilization is clearly separated from all that have gone before by its reliance upon science. Science makes certain demands on social environment, and among the chief of these is surely freedom of the mind. Without such freedom, our scientific system could not exist or progress : without it, representative institutions cannot be maintained. Milton saw these things very clearly, and it was in the early days of the Royal Society that he wrote:

“. . . True Liberty

.. . always with right Reason dwells

Twinn'd, and from her hath no dividual being.

Reason in Man obscured or not obeyed

Immediately inordinate desires

And upstart passions catch the Government

From Reason, and to servitude reduce

Men, till then free."

"Paradise Lost", Book XII, 83-90.

We are witnesses of the simultaneous destruction in several parts of the world of the twins-liberty and reason-and the consequent deterioration of science. We see reason not only obscured and disobeyed but even ousted by unreal creatures of the imagination-'racial consciousness', 'national self-sufficiency', 'the leadership principle'-or one or other of the chimæras of the totalitarian States. Some peoples have been caught thereby from reason, so that the desires and passions of their Governments have already reduced men to servitude, and are on their way to reduce science to nothingness. We have seen a great country, until of late rightly proud of its universities and its scientific achievements, abandoning its belief in reason, destroying the careers of a fifth of its scholars and, by rendering the position of all insecure, humiliating the profession of learning itself and lowering the whole standard of its civilization.

For, let it be remembered, civilization must depend upon a small minority. Our present civilization is upheld by the critical and creative efforts of a few, whose judgment and knowledge ultimately determine the values of the rest. Only in an atmosphere of freedom can such men make their contribution to their own communities and to the world. The need for the Society for the Protection of Science and Learning to save for the freer parts of the world the learning rejected by these slave States, is the measure of the destruction of freedom.

It is an experience, gathered from history, that the great periods of intellectual activity follow the coincidence of the discovery of important new facts with the wide extension of a sense of personal liberty. Of this relation a fortunate illustration is provided by the seventeenth century, which saw both the foundation of English ideas of liberty and the establishment in England of the scientific disciplines. On these two foundations have been built most of the good things that make up our national life. The other democracies-and it is among democracies only that science seems now to flourish-have had a comparable experience.

The rise in the social valuation of freedom of the mind has, therefore, been of incalculable importance for science. Unfortunately, this great movement has had its own vicissitudes and has brought with it its own dangers. In the eighteenth century, science was still confined to a very small class, within which free opinions passed as common intellectual currency. With the emergence of the liberating influences of the French Revolution, such opinions came to be greatly feared. Active 
measures were taken to stifle them when expressed freely, though if buried in expensively printed works the Governments of their day could afford to treat them with contempt. When the 'atheist' William Godwin brought out his 'Enquiry concerning Political Justice and its Influence on Morals and Happiness" in 1793, it escaped prosecution only because the authorities supposed that little harm could be done by a three-guinea publication! Soon, however, the technical and industrial triumphs of science won it new prestige, so that during the later Victorian age, freedom of the mind came to be less feared. Gradually there came another change. With compulsory State education, the proportion of literates increased enormously. Moreover, new channels were found for the passage of ideas. Cheap printing, a new technique of daily journalism, and then the cinema and the wireless, have increased again the danger of ideas to those who fear them. Inordinate desires and upstart passions have now again caught Governments from reason, and man has again been reduced to servitude. The very products of science have been used to suppress the spirit of science.

Of all forms of checks on reason, that on the universities is the most dangerous and destructive, for it strikes many of those best equipped to determine social values. The totalitarian States have not failed to perceive this. National Socialism is the form of totalitarianism that has been most destructive of science, and National Socialism is, as its exponents never tire of explaining, an attempt to exalt instinct at the expense of reason. Last year, at the celebration of the so-called 'jubilee' of the University of Heidelberg, which was timed to coincide with June 30, the day of the great political massacre of 1934 in Germany, the Minister of Education, Herr Rust, delivered a speech in which he exalted the so-called 'racial instinct' over the disinterested pursuit of scientific truth. The day of the supremacy of the intellect, he assured us, is over. Under National Socialism, through its agent, Herr Rust, who has no sympathy with the great tradition of free thought, the universities have been regimented and those who do not share national socialist views have been eliminated. Science has thereby been degraded and German men of science have been made subservient to the engineers of a ruthless political machine.

In Germany, science has always been essentially a product of university officials, and the amateur has played a minor part in its intellectual life.
But now, not only are its university officials spied upon and kept under a strict rule, but even private workers dare no longer express their opinions. The printing press is as much under control as are universities. What may and what may not be published is determined by men who have repeatedly and publicly expressed their opposition to freedom of the mind. The result has been a general deterioration in the quality of scientific publications in every department from mathematics to anthropology.

Apart from this, what can be said of the scientific literature that has been discouraged or suppressed? What of all'that great output of the German intellect that we might have expected during the last four years? Some of it has appeared in foreign countries as the work of men whose continued activity has been rendered possible by foreign hospitality, and what Germany has lost other countries have gained, but much of the potential output of German men of science has been altogether lost. Nor must we forget the great episode of the 'Burning of the Books' which swept as an epidemic over the university towns of Germany. That event will be long held in memory as a sign of what may happen to men by whom reason is disobeyed and the desire for liberty is lost. It is three centuries since Milton wrote words that are as vivid now as then:

"Pooks are not dead things but do contain a potency of life in them to be as active as that soul was whose progeny they are. Who kills a man, kills a reasonable creature; but he who destroys a book kills reason itself, kills the image of God. We should be wary therefore what persecution we raise against the living labours of public men, how we spill that seasoned life of man, preserved and stored up in books ; since a kind of homicide may be thus committed, sometimes a martyrdom; and if it extend to the whole impression, a massacre, whereof the execution ends not in the slaying of an elemental life but strikes at the breath of Reason itself ; slays an Immortality rather than a Life."

Milton saw that freedom of thought is possible only under free social conditions. Many British men of science appear to be indifferent to the application of this essential principle of progress. They hold aloof from the great social questions of the day and seem to disregard the activities of forces destructive to the very world of science. We would not wish men of science to become politicians, but surely they should indicate with no uncertain voice their determination to resist those dark forces of unreason implicit in the regimes that would destroy scientific ideals. 